Andreász Kosztopulosz - Éva Kuruczleki (eds.) (2020): The Challenges of Analyzing Social and Economic Processes in the 21st Century. University of Szeged Faculty of Economics and Business Administration, Szeged, https://doi.org/10.14232/casep21c.11

\title{
Successes and failures in Hungarian family businesses
}

\author{
Máté Repisky - Éva Málovics - Gergely Farkas
}

Family business researchers widely investigated the loss or the threatened loss of socioemotional wealth. Another growing theme within entrepreneurship is the consequences of business failures affecting entrepreneurs. However, these two fields rarely overlapped. The aim of this study was to explore different challenging events' effects on the family entrepreneurs and to identify the factors that can determine the successfulness of the coping strategies.

In this study, we present three case studies about family enterprises, which went through a challenging period and balanced between failure and success. In two cases the main challenges rooted in familiness of the enterprises and in the third case the challenge came from external regulatory change. The two inner challenges were generated by the retirement of the founder and the divorce between the two owners. We could observe both successful and partially successful coping strategies, but the common point was that all of them were strongly rooted in the socio-emotional wealth of family businesses.

Keywords: family business, copreneurship, case study, socio-emotional wealth, coping strategy

\section{Introduction}

Despite family businesses are treated in the literature as a special group, it is also estimated that $65-80 \%$ of firms may be owned or managed by families (MálovicsVajda 2012). In addition, many researchers have pointed out that entrepreneurship is a risky activity as is because there is a significant chance of failure (Fang He et al. 2018, McGrath 1999, Shepherd-Patzelt 2017). This is well illustrated by the KSH (Hungarian Central Statistical Office) analysis of the year 2015, when the five-year survival rate of corporate enterprises in Hungary was $45.1 \%$, while that of sole proprietors was only $27.1 \%$ (KSH 2017). We can assume that most enterprises go bankrupt within a few years or be closed for not meeting owner requirements.

In the field of entrepreneurship research, entrepreneurial failure and its effects on entrepreneurial decision-making is an emerging topic. The preservation of the socio-emotional wealth is an emerging topic in the family business studies, but until now these two topics were rarely connected in the literature (Shepherd 2016, Shepherd-Patzelt 2017). In case of family businesses, the financial (and even emotional) burden of entrepreneurial failure is not only taken by the entrepreneur person but also by the family. Therefore, examining the entrepreneur within the family system can provide a more complete picture of the effects of failure (Shepherd-Patzelt 2017).

Considering the above, our research questions are how family businesses are affected by different crisis situations; how family entrepreneurs choose coping methods and with what kind of results. In the first part of the study, we present the key definitions such as family businesses; used personality traits and categorization 
of business situations. After that, we summarize the theory of socio-emotional wealth. In the next subchapter, we summarize the used research methodology and sample. The chapter about our results will have three parts: observed personality traits; socioemotional wealth in the case studies and the coping strategy and its successfulness. In the end, we close our study with a brief summary with the key results, limitation and potential next steps in this research theme.

\subsection{Definitions}

During the research, we considered as family businesses the companies in which a family or family association has a decisive influence on the development of the enterprise (Wimmer et al. 2004). This is most often manifested by the facts that one family is the majority owner of the business and/or the key decision-making positions are held by one family. A special case of family businesses is the so-called copreneurship, where a couple trying to manage their business and personal relationships at the same time (de Bruin-Lewis 2004). The copreneurship is usually started by a married couple, but broad definitions do not require marriage, nor different gender. In practice, this means that a couple in a romantic relationship owns and/or controls one or more businesses.

One of the key topics of early entrepreneurship studies was the personality traits of the entrepreneurs with research questions like this: can we separate entrepreneurial personality from the rest of the society? (Carsrud-Brännback 2011) In our research, we will use traits from four different personality trait theories. One of them is maybe the most widespread one, the Big Five model. The locus of control theory was developed by Rotter (1966) and we can say that people who believe in an internal locus of control tend to be entrepreneurs (Shane et al. 2003). Another key trait of entrepreneurs can be the achievement motivation (Stewart et al. 1999, Shane et al. 2003), which was first defined by McClelland in the theory of learned needs (McClelland 1961). The last used personality trait model is the three dimensioned version of entrepreneurial orientation (Bolton-Lane 2012), which was developed to research persons contrary to the original model, which was used for organizational level (Lumpkin-Dess 1996). In Table 1 from the above-mentioned personality models, we only defined those traits that we will use in the analysis. 
Table 1 Personality traits used in the research

\begin{tabular}{|c|c|c|}
\hline CONCEPT & DEFINITION & SOURCE \\
\hline $\begin{array}{l}\text { Internal locus of } \\
\text { control }\end{array}$ & $\begin{array}{l}\text { People believe that they have somewhat } \\
\text { personal control over the outcome of events } \\
\text { in their lives. }\end{array}$ & $\begin{array}{c}\text { Rotter 1966; } \\
\text { Levenson 1974; } \\
\text { Kaufmann-Welsh } 1995\end{array}$ \\
\hline $\begin{array}{l}\text { External locus of } \\
\text { control }\end{array}$ & $\begin{array}{l}\text { People believe that they are controlled by } \\
\text { powerful forces (fortune, luck) or } \\
\text { influential individuals in their lives. }\end{array}$ & $\begin{array}{c}\text { Rotter } 1966 \\
\text { Levenson } 1974 \\
\text { Kaufmann-Welsh } 1995\end{array}$ \\
\hline $\begin{array}{l}\text { Conscientiousness } \\
\text { (part of Big Five) }\end{array}$ & $\begin{array}{l}\text { People's tendency to display self-discipline, } \\
\text { orderliness, prudence, diligence and } \\
\text { foresight in their lives. }\end{array}$ & Little 2017 \\
\hline $\begin{array}{c}\text { Openness to } \\
\text { experience } \\
\text { (part of Big Five) }\end{array}$ & $\begin{array}{l}\text { People who are open to new ideas, } \\
\text { relationships, adventure, and can see the } \\
\text { world in a creative way. }\end{array}$ & Little 2017 \\
\hline $\begin{array}{l}\text { Achievement } \\
\text { Motivation } \\
\text { (Part of Learned } \\
\text { Needs) }\end{array}$ & $\begin{array}{l}\text { People who prioritize excellence, tend to } \\
\text { choose goals with medium difficulty, } \\
\text { display personal responsibility and planning } \\
\text { ahead. }\end{array}$ & $\begin{array}{c}\text { Lang-Fries 2006; } \\
\text { Germak-Robinson 2014; } \\
\text { Pardee 1990; } \\
\text { Shane et al. 2003 }\end{array}$ \\
\hline $\begin{array}{l}\text { Innovation } \\
\quad \text { (Part of } \\
\text { Entrepreneurial } \\
\text { Orientation) }\end{array}$ & $\begin{array}{l}\text { People's tendency to display creativity, new } \\
\text { solutions in the form of device or method. }\end{array}$ & Farkas et al. 2014, 91. \\
\hline $\begin{array}{l}\text { Risk-Taking } \\
\quad \text { (Part of } \\
\text { Entrepreneurial } \\
\text { Orientation) }\end{array}$ & $\begin{array}{l}\text { People's tendency to deal with uncertainty } \\
\text { (during entrepreneurial acts). }\end{array}$ & Szerb-Lukovszki 2013 \\
\hline
\end{tabular}

Source: own construction

Fang He et al. (2018) use a simple, yet useful graph to group business situations based on whether the business is performing below or above expectations in one dimension, or whether the entrepreneur is continuing or interrupting the activity in the other dimension (Figure 1). Based on this approach we will judge the success of each coping strategy during the analysis. According to a widely accepted definition, failure is the closure of a business that has fallen short of its goals or failed to meet its owners' expectations (Cope 2011, McGrath 1999, Ucbasaran et al. 2010). Therefore, closing a business does not mean bankruptcy in each case (Cope 2011, Simmons et al. 2014, Ucbasaran et al. 2010), so bankruptcy is only a subset of business failure (Fang He et al. 2018). Another important distinction is that "voluntary exit" can happen when an entrepreneur leaves or closes a business that meets expectations (Fang He et al. 2018) and this is not considered as a failure, even though it may mean the end of the business. We consider a coping strategy to be successful if the business continues to live up to expectations, and in all other cases, we will categorize cases as unsuccessful or partially successful. 
Figure 1 Categorizing Business Situations

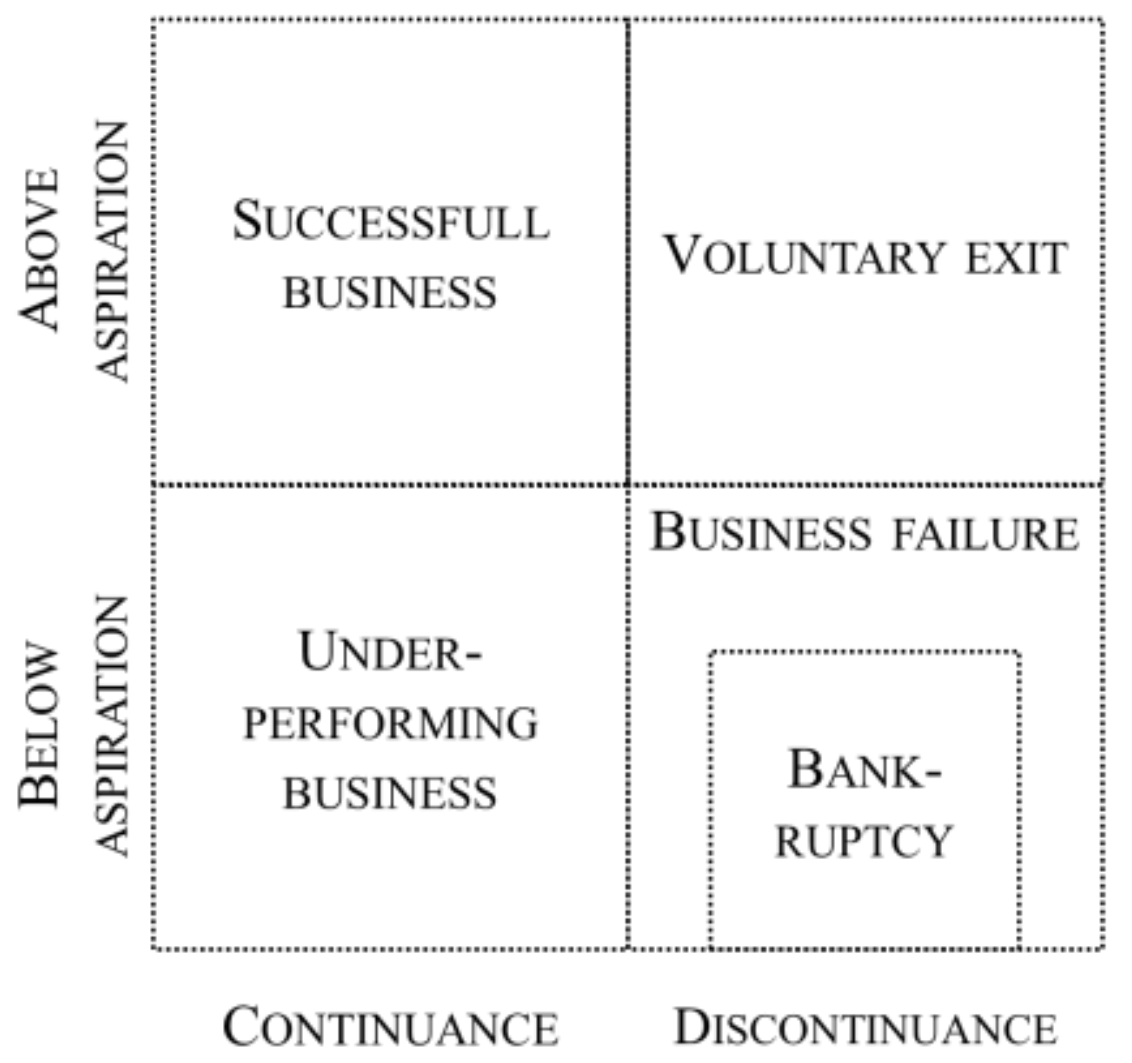

Source: own construction after Fang He et al. 2018, p. 609

\subsection{Socio-Emotional Wealth (SEW)}

The concept of socio-emotional wealth (SEW) is gaining popularity in cases when differentiating between family and non- family businesses is required. As Shepherd (2016) summarizes, many studies have already concluded that family businesses make decisions to preserve SEW in the long run. SEW has five dimensions discussed by Berrone et al. (2012):

1. Family control and influence: The extent of a family controls a business, either formally or informally through leadership and ownership.

2. Family members' identification with the firm: This may take the form of the company is named after the family name or they are considering the business as an extension of their family. The effect of this may be that the family is more interested in the image of the business since it also expresses an opinion about the family. At the same time, this appears as acting more frequent in a socially responsible way. 
3. Binding social ties: This is about social relationships of the family what extends to kinship relationships and close, trusting relationships with those who work there, thus raise their level of social capital and solidarity. This attitude grants stability for the company and its employees. As in the previous dimension, this also supports community involvement and sponsorship.

4. Emotional attachment: If the family and the business are closely linked, emotions can pass from one system to another in case of important events (for example divorce, succession, illness, family or business loss, loss of income, etc.). The emotional attachment of the family to the business and the employees may result in altruistic acts, but negative emotions can lead to a dysfunctional group.

5. Renewal of family bonds to the firm through dynastic succession: it covers the intention that the founders would like to handle the business down to the future generations. In this approach, business is not only a property that they get or give away but an important part of family tradition, therefore succession is usually one of the main goals of family businesses.

Aldrich and Cliff (2003) examined the family embeddedness in the enterprise and raised the question of whether the success or failure of a new business can affect the family system more. Several studies have confirmed that business failure can lead to divorce (Cope 2011, Repisky 2018a, Singh et al. 2007) or the entrepreneur can lose the role of the head of the family (Repisky 2018a). The SEW concept supports the idea that the two systems: family and business can have strong interaction, especially in a variety of crisis situations.

Anderson (2003) emphasized that the higher the level of expected negative emotions, the more likely it is that the individual will delay an activity, so people are trying to minimize the probability and severeness of negative emotions. Furthermore, irreversible decisions only exacerbate the former effect (Anderson 2003), such as closing a business (Repisky 2018b). There may be several types of fear of failing in such situations. Conroy, Kaye and Fifer (2007) and colleagues presented five fears of failing: fears of experiencing shame and embarrassment, fears of devaluing one's selfestimate, fears of having an uncertain future, fears important others losing interest, and fears of upsetting important others.

In connection with the above-mentioned fears one of the central topics in the research of entrepreneurial failure is the stigma what the entrepreneur gets following the failure: the stigma of failed entrepreneur (Repisky 2018a, Simmons et al. 2014, Singh et al. 2015, Ucbasaran et al. 2013; Wiesenfeld et al. 2008). The stigma may arise from the fact that society penalizes the entrepreneurs who failed because they infringed social norms (Elster 1996). We can define stigma as a form of shame on a person that negatively affects their image and reputation (Cotterill 2012, Wiesenfeld et al. 2008). We have seen that several dimensions of SEW lead to a strong bond between firm and family, so the image of the firm may tend to match the image of the family. In the event of entrepreneurial failure, they may feel that not only the family members who were involved in the business but the whole family will be stigmatized by society. This further increases the tendency to do their best to save the business. 


\section{Research methodology and introduction of the sample}

The aim of this research was to explore the impact of different crisis situations on family entrepreneurs and to find out which factors determine the successfulness of the coping strategies. Because of the chosen aim, our research is explanatory qualitative and we used multiple case studies. We chose to use case studies because this methodology is suitable to introduce the sometimes complex crisis events and coping strategies. We would like to emphasize that this is a qualitative study so we cannot generalize our results, but we can transfer them into future researches (Szokolszky 2004). Moreover, there is an exchange between reliability and validity, and in our case, the degree of validity will be higher, because of the qualitative methods (Babbie 2008).

The sample consisted of Hungarian family entrepreneurs and (potential) successors. Another important criterion was that their company went through a crisis in the recent past. The researched sample's main characteristics are summarized in Table 2. In agreement with the approach of Byrne and Shepherd (2015), we sought to gather a diverse range of cases as it was possible, to explore the researched phenomena's wider range. The focus topic of the first case was crisis in the owner married couple's personal life, this is why the case name is "Copreneurship in crisis". In the second case, we can follow a market leader company's journey during difficult period. In the third case, the owner of the company wanted to retire and to pass on the leadership to his children what caused a crisis.

Table 2 Main characteristics of our sample

\begin{tabular}{|c|c|c|c|c|c|}
\hline Nr. & $\begin{array}{l}\text { Name of the } \\
\text { case study }\end{array}$ & $\begin{array}{c}\text { Type of } \\
\text { business }\end{array}$ & $\begin{array}{l}\text { Inter- } \\
\text { viewee }\end{array}$ & Role in the enterprise & $\begin{array}{c}\text { Number } \\
\text { of } \\
\text { interviews }\end{array}$ \\
\hline \multirow{3}{*}{1.} & \multirow{3}{*}{$\begin{array}{l}\text { Copreneurship } \\
\text { in crisis }\end{array}$} & \multirow{3}{*}{$\begin{array}{l}\text { Portfolio } \\
\text { (multiple } \\
\text { enterprises) }\end{array}$} & Husband & Owner, idea maker & 3 \\
\hline & & & Wife & Owner, implementer & 3 \\
\hline & & & Son & Successor & 1 \\
\hline \multirow{3}{*}{2.} & \multirow{3}{*}{ Market leader } & \multirow{3}{*}{ IT } & Father & Owner, idea maker & 1 \\
\hline & & & Daughter & Potential successor & 1 \\
\hline & & & Son & Potential successor & 1 \\
\hline \multirow{2}{*}{3.} & \multirow{2}{*}{ Retirement } & \multirow{2}{*}{ IT } & Father & Founder, advisor & 1 \\
\hline & & & Son & Successor & 1 \\
\hline
\end{tabular}

Source: own construction 
We made unstructured depth interviews with the interviewees, so we only defined some key topics instead of fixed interview threads. This data gathering method is widely used in grounded theory because in this way we can get know better the interviewees perspective and they have bigger freedom to express what is important for them. The interviews were conducted at different times, and in the $1^{\text {st }}$ case, we could make longitudinal interviews (before and after the crisis event) to get a more complex picture.

Two researchers made the analysis independently on the typed interviews or on the original audio files. The coding and analysis were conducted in three phases based on the principles of grounded theory:

1. In phase one, we coded the interviews nearly row to row, independently from the known theories. This is the so-called open or substantive coding (Mitev 2012). In this very opened coding method, the most important themes had the possibility to emerge from the raw data (Kucsera 2008). In this early stage of coding, we used so-called in vivo codes, which mean we cited the words of the interviewee as codes because they reflect better on the respondent's perspective (Charmaz 2006).

2. In the second phase, we arranged the existing codes into larger logical units, categories with the help of tables. As a result, these categories were on a higher level of abstractness and they can be the basic elements of the theory development (Gelencsér 2003). To make easier the theory making, we made bigger matrixes with the relevant categories case by case for each bigger topic (Byrne-Shepherd 2015).

3. The two researchers, who made the analysis, conducted the first two phases independently from each other. We discussed and integrated our personal results only in the third phase. We made this to mitigate the researchers' subjectivity.

\section{Results}

We divided our results into three main parts. First, we describe the observed personality traits. After that, we present the cases from the dimensions of socioemotional wealth. Finally, we briefly summarized the process of each crisis, from the antecedents, through the coping strategies, to the successfulness of these strategies.

\subsection{Observed entrepreneurial personality traits}

We could infer to more personality traits of the interviewed entrepreneurs. However, this categorization should be treated with limitations because this is based on interview and not real personality tests.

In our first case ("copreneurship in crisis") both members of the couple have two personality traits that appeared more strongly. 
1. The man believed in an internal locus of control in his entrepreneurial life, so he thought that he can control his life. After the crisis in his personal life, he blamed his wife for everything (external locus of control - powerful others). His other dominant personality trait was the innovativeness, which was confirmed by his wife. He always came up with new enterprise ideas; this why felt so comfortable in managing the strategic level of their companies. From the perspective of the Big Five theory, we can say that he is open, he always searches for new opportunities and ideas.

2. In the interviews with the woman, two personality traits appeared more dominantly. In her case, the external locus of control was more decisive. In their business life, her husband was the more dominant, and after the divorce, she blamed her husband for everything. Contrary, she is very conscientious and precise, she is a real implementer. Therefore they complement each other so well in their business life.

In our second case ("market leader") it was interesting that the observed personality traits characterizing not only the founder but his whole family and even some cases his enterprise too.

- The most unusual trait was the trans-generational achievement motivation, which was learned from father to son in their family. It means that most of their ancestors were striving to excellence, to become better and better what they are doing regardless of their profession, as they are doing it now in their enterprise.

- The whole family strongly believes in an internal locus of control, after such huge challenge, what their experienced, they immediately were looking for what they could do differently, how they could improve the situation of their company.

- Moreover, the innovativeness was not only the family's trait, but the organizational culture of their company was shaped similarly. The past years they employ people who are innovative, which strengthen not only this trait but the market position of the company.

In our third case ("retirement"), all of the family members, who participated in the management of their company, have similar observed personality traits.

- All of them are strongly innovative, if one of their ideas did not work, they immediately started to work on something new. This common direction change required continuous learning and this leads us our next trait.

- They did not afraid of risk-taking during the introduction of their innovations. Moreover, if their family business or any family members were threatened with a huge challenge or crisis they were ready to take a significant risk.

We think that more personality traits that characterize entrepreneurs according to the entrepreneurship literature were outlined during the interviews. In the following chapter, we will see that these personality traits will be of great help for the investigated families during the challenging events. 


\subsection{Appearance of SEW dimensions in the researched cases}

The socio-emotional wealth appeared in all cases, even if some of the dimension were stronger or weaker in each case. In this chapter, we briefly summarized this.

Table 3 SEW appearance in the $1^{\text {st }}$ case

\begin{tabular}{c|c}
$\begin{array}{c}\text { Family control and influence } \\
\begin{array}{c}\text { Identification of family members } \\
\text { with the firm }\end{array}\end{array}$ & $\begin{array}{l}50-50 \% \text { ownership and leadership in the hand of the couple } \\
\text { in the case of their portfolio of enterprises. }\end{array}$ \\
$\begin{array}{c}\text { Permanent communication about business decisions in } \\
\text { private life. } \\
\text { Strong connection with their colleagues (business trips and } \\
\text { parties, long-term employment). }\end{array}$ \\
$\begin{array}{c}\text { Emotional attachment of family } \\
\text { members }\end{array}$ & $\begin{array}{c}\text { They were emotionally attached to their companies. } \\
\text { Renewal of family bonds through } \\
\text { dynastic succession }\end{array}$ \\
\hline
\end{tabular}

Source: own construction

As we see in Table 3 , in our $1^{\text {st }}$ case most of the dimensions of SEW were strongly present in the copreneurs' enterprise portfolio, even if they don't have real succession strategy and their emotional attachment is not distributed equally among their companies. The reason behind the unbalanced emotional attachment can be they have too many firms simultaneously and in this way they have less time and energy for each one, they will have favourites.

Table 4 SEW appearance in the $2^{\text {nd }}$ case

\begin{tabular}{|c|c|}
\hline Family control and influence & Very centralized ownership, $100 \%$ owned by the founder. \\
\hline $\begin{array}{l}\text { Identification of family members } \\
\text { with the firm }\end{array}$ & $\begin{array}{l}\text { The family and business intertwined, the children were } \\
\text { socialized in the company (they wrote their homework and } \\
\text { lived their hobbies there). }\end{array}$ \\
\hline Binding social ties & $\begin{array}{l}\text { Long-term employment (in the case of more employee this } \\
\text { means more than twenty years) and democratic, flat } \\
\text { organizational structure (equality). }\end{array}$ \\
\hline $\begin{array}{c}\text { Emotional attachment of family } \\
\text { members }\end{array}$ & $\begin{array}{l}\text { The whole nuclear family works in the company and } \\
\text { connected emotionally to it. }\end{array}$ \\
\hline $\begin{array}{l}\text { Renewal of family bonds through } \\
\text { dynastic succession }\end{array}$ & $\begin{array}{l}\text { Two potential successor works in the company; however, } \\
\text { the founder does not think they will take over the family } \\
\text { business. }\end{array}$ \\
\hline
\end{tabular}

Source: own construction

In our opinion, the socio-emotional wealth is more significant in our $2^{\text {nd }}$ case, even if the succession is uncertain (Table 4). We can see that the $3^{\text {rd }}$ company has similarities with the $2^{\text {nd }}$ one according to more dimensions of SEW. Similarly, the whole company is owned by the founder, the father; the long-term employment is important, and more family worked or still working in the company (Table 5). 
Table 5 SEW appearance in the $3^{\text {rd }}$ case

\begin{tabular}{cl}
\hline Family control and influence & $\begin{array}{l}\text { Company-owned by the father 100\%, the control totally in } \\
\text { the hand of the family. } \\
\text { The founder identifies himself with the successful } \\
\text { innovation of the company. } \\
\text { Lith the firm }\end{array}$ \\
$\begin{array}{c}\text { Linding social ties } \\
\text { not only the employees but one of their subcontractor too. } \\
\text { Everyone from the nuclear family worked or still working } \\
\text { in the company. Serious risk-taking for the success of the } \\
\text { company. }\end{array}$ \\
$\begin{array}{c}\text { Renewal of family bonds through } \\
\text { mynastic succession }\end{array}$ & Two potential successors. \\
\hline
\end{tabular}

Source: own construction

\subsection{Coping strategies and the results of these strategies}

We will present the coping process in four steps: "wind of change"; challenging event itself; used coping strategies and the results of the whole process. In one case we will see that the challenging had more rounds and in this way, some of the steps will occur more times.

In the case called "copreneurship in crisis" the challenging event and the solution of it occurred as we detailed below:

1. The "wind of change": Before the challenging event there was some sign of it, the couple's relationship becomes worse, so the trust between them decreased also from a business perspective. Moreover, the man initiated to start selling some of their less important assets or some of their companies.

2. The challenge: This distrust leads to a divorce and a hostile atmosphere between them. They blamed each other for everything. Obviously, this made the joint leadership nearly impossible, so their whole portfolio of enterprises' future becomes uncertain.

3. Coping strategies: Because of the binding social ties with their employees, they tried to solve the conflict between them, at least the business side of it. First, they divided their assets and companies equally. The former wife tried to save and operate the companies that became hers. Luckily one of their children appeared as a co-manager in the companies of the mother. Contrary, the husband kept only one enterprise, because of his personality traits, he was in creative and strategic tasks, but not in everyday operation.

It was obvious, that their sought for a solution not because of the financial wealth, but the socio-emotional wealth, because if they sold everything they can get back their money with out problem (even some debt could make it a little harder). So, their decision was not led by business logic. It is more prominent in the case of the former wife, her coping strategy rooted in the SEW: she was very attached to her business emotionally; the good, trustful relationship with her colleagues helped to get through this hard period; and even one of her sons joined as a potential successor in the everyday operation of her companies. 
4. Result of the coping strategies: From the interviews, we got to know that they had 12 companies before the challenging event. After the crisis, we can say that two of them are successful businesses because they are above the owners' aspirations. They have seven more under-performing businesses, from which in the case of four there is not even asset or revenue and in the case of the other three there are significant assets, but they are generating a loss. The fate of the last three companies was faded; they did not mention them in the interviews. The reason can be that was already sold or closed, or these three companies were not so important from emotional and/or financial aspect.

The case called "market leader" was a little bit different than the other two cases, because here the challenge comes from an external source and not from the family.

1. The "wind of change": They did not foresee the coming challenge, but there were signs that predicted it. On their market, there was a previous powerful political activity, and the legislation mechanism was very fast in Hungary.

2. The challenge: As we mentioned in this case the challenge came from an external source in the form of a very fast regulatory change (3 weeks after the announcement, the new regulation came into force). This new regulation eliminated their whole domestic market and they were not prepared for this hard situation. They had only a few weeks to react and some extra time what the companies emotional and financial reserves allowed.

3. Coping strategies: They reaction was to change their business model as fast as they can, so they tried to develop a product for the international market. Luckily, they had a half-finished software that had the potential to become an internationally successful product.

In this hard period, it was a key issued that not only the family members were emotionally attached to the company, but their employees too. Another important segment was they construct a very loyal and creative organization, which kept the experts there. In this way, we can say that the coping strategy rooted in the emotional attachment and in the binding social ties (two dimensions of the SEW).

4. Result of the coping strategies: The company was a market leader at the domestic market, but after the regulatory change it became an underperforming business. Due to the coping strategy, the company become even stronger and successful on the international market. In their case, it seems true that "what does not kill you makes you stronger".

Our last case, the so-called "retirement" the situation was the most complicated because after the first challenge there were other two, so they have to solve three crises in a row.

1. The "wind of change": The researched company's past was full of direction changes, which needed innovativeness, frequent renewals and continuous learning. Because of the age of the founder, this continuous changing became tiring. 
2. Challenge 1.: Because of the previous reasons the founder decided, he will retire. Parallel with this, a new business opportunity also emerged, which required completing a training programme.

3. Coping strategy 1.: Because none of the children seemed to apply for the role of the leader, the father gave an ultimatum to his family. So, one of them becomes the new leaders or he will close this and other two of his companies. This gave the necessary push to his sons, two successors (an IT specialist and a biologist) applied and made a deal with their father, that he will stay in an advisory role. Moreover, all three of them finished the necessary training programme to grab the new business opportunity.

4. Result of the $1^{\text {st }}$ coping strategy: In the case of the researched organization, because of the two successors, the strategy reaches its aim, the company stayed successful. On the other hand, from the other two companies, one of them remained without successor, so the founder had to make a voluntary exit, close a company that reached his aspirations. All together the coping strategy was only partially successful. In the next point, we will only follow the company with the two successors.

5. Challenge 2.: With time the two successors confronted because they had different ideas about how to lead the company, which made their relationship worse.

6. Coping strategy 2.: This situation led to that, the IT specialist left their IT company and he moved abroad for a new job opportunity.

7. Challenge 3.: The remained biologist successor had fewer necessary expertise, because of his profession. This can be the reason why he led this IT company to inoperability, which was the third challenge of this family business.

8. Coping strategy 3.: The only solution to save the family business was that the IT specialist came back to their company.

9. Result of the coping strategies: As we saw from the original three companies only two survived in the researched period because of the lack of a successor, the founder had to close one of them. From the surviving two one of them faced multiple challenges and nearly bankrupted, but in the end, it got back its market position, so they coped with the core challenge, the retirement of the founder. From the perspective of the enterprise portfolio, we can say the coping strategies were only partially successful.

For all of the coping strategies, the motivation and the solution came from the dimensions of socio-emotional wealth. For example, the successor only joined to the company because of the family ties, but after that, they get more and more emotionally connected to the company, this why they took the necessary risks to keep alive the family business (finish training programme; came back from a successful other business). However, the most obvious SEW dimension was the "Renewal of family bonds through dynastic succession" because they took over the leadership of their company. 


\section{Summary}

The aim of this research was to explore the impact of different crisis situations on family entrepreneurs and to find out which factors determine the successfulness of the coping strategies. During the three case studies we saw successful and partially successful coping strategies, but it was common in them, that all of them rooted in the socio-emotional wealth. This research highlighted that the family involvement can have a dual role in the family businesses, it can be the root of the crisis, but at the same the solution too in the form of SEW.

Table 6 Results of the study briefly

\begin{tabular}{cccc}
\hline $\begin{array}{c}\text { Number of } \\
\text { the case }\end{array}$ & The root of the challenge & $\begin{array}{c}\text { Root of the } \\
\text { coping strategy }\end{array}$ & $\begin{array}{c}\text { Result of the coping } \\
\text { strategy }\end{array}$ \\
\hline 1. & Family (divorce) & SEW & Partial success \\
2. & $\begin{array}{c}\text { Regulatory change } \\
\text { Family (retirement, conflict of } \\
\text { the successors) }\end{array}$ & SEW & Success \\
& SEW & Partial success \\
\hline
\end{tabular}

Source: own construction

As every study it has some limitation, some of them come from the research methods (cannot be generalized, using unstructured interviews) and other come from the research theme itself (reliability what the interviewees said about this unpleasant topic, limited access to the sample, time lag between the interviews and the event).

According to our results, we saw more potential next steps in this research. The most obvious is to process more cases or make new interviews with the existing three companies' leaders to get to know the long-term effects of the challenges. This explanatory study revealed the core factors of the researched phenomena, so in the following interviews, we can use semi-structured interviews.

\section{Acknowledgements}

This research was supported by project nr. EFOP-3.6.2-16-2017-00007, titled Aspects on the development of intelligent, sustainable and inclusive society: social, technological, innovation networks in employment and digital economy. The project has been supported by the European Union, co-financed by the European Social Fund and the budget of Hungary.

\section{References}

Aldrich, H. E. - Cliff, J. E. (2003): The pervasive effects of family on entrepreneurship: Toward a family embeddedness perspective. Journal of business venturing, 18, 5, 573-596. 
Anderson, M. C. (2003): Rethinking interference theory: Executive control and the mechanisms of forgetting. Journal of Memory and Language, 49, 415-445.

Babbie, E (2008): The basics of social research. Belmont, CA: Thomson/Wadsworth. Chicago.

Berrone, P. - Cruz, C. - Gomez-Mejia, L. R. (2012): Socioemotional wealth in family firms: Theoretical dimensions, assessment approaches, and agenda for future research. Family Business Review, 25, 3, 258-279.

Bolton, D. L. - Lane, M. D. (2012): Individual entrepreneurial orientation: development of a measurement instrument. Education + Training, 54, 2/3, 219-233.

Byrne, O. - Shepherd, D. A. (2015): Different strokes for different folks: Entrepreneurial narratives of emotion, cognition, and making sense of business failure. Entrepreneurship Theory and Practice, 39, 2, 375-405.

Carsrud, A. - Brännback, M. (2011): Entrepreneurial motivations: what do we still need to know? Journal of Small Business Management 49, 1, 9-26.

Charmaz, K. (2006): Constructing grounded theory: A practical guide through qualitative analysis. Sage Publications Ltd., London.

Conroy, D. E. - Kaye, M. P. - Fifer, A. M. (2007): Cognitive links between fear of failure and perfectionism. Journal of Rational-Emotive \& Cognitive-Behavior Therapy, 25, 4, 237-253.

Cope, J. (2011): Entrepreneurial learning from failure: An interpretative phenomenological analysis. Journal of Business Venturing, 26, 6, 604-623.

Cotterill, K. (2012): A Comparative Study of Entrepreneurs' Attitudes to Failure in Technology Ventures. International Journal of Innovation Science, 4, 2, 101116.

De Bruin, A. - Lewis, K. (2004): Toward enriching united career theory: familial entrepreneurship and copreneurship. Career Development International, 9, 7, $638-646$.

Elster, J. (1996): Rationality and the Emotions. The Economic Journal, 106, 438, 1386-1397.

Fang He, V. - Sirén, C. - Singh, S. - Solomon, G. - von Krogh, G. (2018): Keep calm and carry on: Emotion regulation in entrepreneurs' learning from failure. Entrepreneurship Theory and Practice, 42, 4, 605-630.

Farkas, G. - Kincsesné Vajda, B. - Málovics, É. (2014): The influence of values on the strategic orientations of entrepreneurs. Responsible Innovation, SZTE GTK, Szeged, 85-99.

Gelencsér, K. (2003): Grounded theory. Szociológiai szemle, 2003/1, 143-154.

Germak, A. J. - Robinson, J. A. (2014): Exploring the motivation of nascent social entrepreneurs. Journal of Social Entrepreneurship, 5, 1, 5-21.

Kaufmann, P. - Welsh, D. (1995): Locus of control and entrepreneurship in the Russian Republic. Entrepreneurship: Theory and Practice, 20, 43-56. 
KSH (2017): Vállalkozások demográfiája, 2015. Központi Statisztikai Hivatal, Budapest.

http://www.ksh.hu/apps/shop.kiadvany?p_kiadvany_id=936028\&p_temakor_kod=KSH\&p_session_id=300419973154990\&p_ lang=HU, Accessed: December 14, 2017.

Kucsera, Cs. (2008): Megalapozott elmélet: egy módszertan fejlődéstörténete. Szociológiai Szemle, 3, 92-108.

Lang, J. W. B. - Fries, S. (2006): A revised 10-item version of the Achievement Motives Scale: Psychometric properties in German-speaking samples. European Journal of Psychological Assessment, 22, 216-224.

Levenson, H. (1974): Activism and powerful others: Distinctions within the concept of internal-external control. Journal of Personality Assessment, 38, 377-383.

Little, B. R. (2017): Én, jómagam és a többiek. HVG Könyvek, Budapest.

Lumpkin, G. T. - Dess, G. G. (1996): Clarifying the Entrepreneurial Orientation Construct and Linking It to Performance. Academy of Management Review, 21, 1, 135-172.

Málovics, É. - Kincsesné Vajda, B. (2012): A családi vállalkozások főbb problémái. In Bajmócy, Z. - Lengyel, I. - Málovics, Gy. (eds.): Regionális innovációs képesség, versenyképesség és fenntarthatóság, JATEPress, Szeged, 378-393.

McClelland, D. C. (1961): The Achieving Society. Princeton University Press, Princeton.

McGrath, R. (1999): Falling forward: Real options reasoning and entrepreneurial failure. Academy of Management Review, 24, 13-30.

Mitev A. Z. (2012): Grounded theory, a kvalitatív kutatás klasszikus mérföldköve. Vezetéstudomány, 43, 1, 17-30.

Pardee, R. L. (1990): Motivation Theories of Maslow, Herzberg, McGregor \& McClelland. A Literature Review of Selected Theories Dealing with Job Satisfaction and Motivation. https://eric.ed.gov/?id=ED316767, Accessed: February 21, 2018.

Repisky, M. (2018a): Vállalkozói kudarc - A vég, vagy egy új kezdet? Vezetéstudomány, 49, 4, 12-22. o.

Repisky, M. (2018b): Vállalkozói kudarc késleltetése - Mi van a döntés mögött? In Dobrai K. - László Gy. - Sipos N. (eds.): I. Farkas Ferenc Nemzetközi Tudományos Konferencia. Pécsi Tudományegyetem Közgazdaságtudományi Kar Vezetés- és Szervezéstudományi Intézet, 227-242.

Rotter, J. B. (1966): Generalized expectancies of internal versus external control of reinforcement. Psychological Monographs, Medline, 80, 1, 1-28.

Shane, S. - Locke, E. A. - Collins, C. J. (2003): Entrepreneurial motivation. Human resource management review, 13, 2, 257-279.

Shepherd, D. A. (2016): An emotions perspective for advancing the fields of family business and entrepreneurship: Stocks, flows, reactions, and responses. Family Business Review, 29, 2, 151-158.

Shepherd, D. A. - Patzelt, H. (2017): Trailblazing in entrepreneurship: Creating new paths for understanding the field. Springer. 
Simmons, S. - Wiklund, J. - Levie, J. (2014): Stigma and business failure: implications for entrepreneurs' career choices. Small Business Economics, 42, 3, 485-505.

Singh, S. - Corner, P. - Pavlovich, K. (2007): Coping with entrepreneurial failure. Journal of Management \& Organization, 13, 331-344.

Singh, S. - Corner, P. D. - Pavlovich, K. (2015): Failed, not finished: A narrative approach to understanding venture failure stigmatization. Journal of Business Venturing, 30, 1, 150-166.

Stewart, JR., W. H. - Watson, W. E. - Carland, J. C. - Carland, J. W. (1999): A proclivity for entrepreneurship: a comparison of entrepreneurs, small business owners, and corporate managers. Journal of Business Venturing, 14, 189-214.

Szerb, L. - Lukovszki, L. (2013): Magyar egyetemi hallgatók vállalkozási attitüdjei és az attitüdöket befolyásoló tényezők elemzése a GUESSS-felmérés adatai. Vezetéstudomány, 44, 7/8, 30-40.

Szokolszky, Á. (2004): Kutatómunka a pszichológiában. Osiris Kiadó, Budapest.

Ucbasaran, D. - Shepherd, D. - Lockett, A. - Lyon, S. J. (2013): Life after business failure: the process and consequences of business failure for entrepreneurs. Journal of Management, 39, 1, 163-202.

Ucbasaran, D. - Westhead, P. - Wright, M. - Flores, M. (2010): The nature of entrepreneurial experience, business failure and comparative optimism. Journal of Business Venturing, 25, 6, 541-555.

Wiesenfeld, B.M. - Wurthmann, K.A. - Hambrick, D.C. (2008): The Stigmatization and Devaluation of Elites Associated with Corporate Failures: A Process Model. Academy of Management Review, 33, 1, 231-251.

Wimmer, R. - Groth, T. - Simon, F. (2004): Erfolgsmuster von Mehrgenerationen Familienunternehmen. Wittener Diskussionspapiere. Sonderheft, Nr 5. 